\title{
Geology
}

\section{Insights on lava-ice/snow interactions from large-scale basaltic melt experiments} Benjamin R. Edwards, Jeffrey Karson, Robert Wysocki, Einat Lev, llya Bindeman and Ulrich
Kueppers

Geology 2013;41;851-854

doi: $10.1130 / G 34305.1$

\section{Email alerting services}

\section{Subscribe}

\section{Permission request}

click www.gsapubs.org/cgi/alerts to receive free e-mail alerts when new articles cite this article

click www.gsapubs.org/subscriptions/ to subscribe to Geology

click http://www.geosociety.org/pubs/copyrt.htm\#gsa to contact GSA

Copyright not claimed on content prepared wholly by U.S. government employees within scope of their employment. Individual scientists are hereby granted permission, without fees or further requests to GSA, to use a single figure, a single table, and/or a brief paragraph of text in subsequent works and to make unlimited copies of items in GSA's journals for noncommercial use in classrooms to further education and science. This file may not be posted to any Web site, but authors may post the abstracts only of their articles on their own or their organization's Web site providing the posting includes a reference to the article's full citation. GSA provides this and other forums for the presentation of diverse opinions and positions by scientists worldwide, regardless of their race, citizenship, gender, religion, or political viewpoint. Opinions presented in this publication do not reflect official positions of the Society.

\section{Notes}

(C) 2013 Geological Society of America

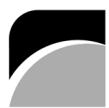

THE

GEOLOGICAL

SOCIETY

OF AMERICA 


\title{
Insights on lava-ice/snow interactions from large-scale basaltic
}

\section{melt experiments}

\author{
Benjamin R. Edwards ${ }^{1}$, Jeffrey Karson², Robert Wysocki², Einat Lev ${ }^{3}$, llya Bindeman ${ }^{4}$, and Ulrich Kueppers ${ }^{5}$ \\ ${ }^{1}$ Department of Earth Sciences, Dickinson College, Carlisle, Pennsylvania 17013, USA \\ 2Department of Earth Sciences, Syracuse University, Syracuse, New York 13244-1070, USA \\ 3Lamont-Doherty Earth Observatory, Palisades, New York 10964-1000, USA \\ ${ }^{4}$ Department of Geological Sciences, University of Oregon, Eugene, Oregon 97403, USA \\ ${ }^{5}$ Department of Earth and Environmental Sciences, University of Munich (LMU), 80539 Munich, Germany
}

\section{ABSTRACT}

Quantitative measurements of interactions between lava and ice/snow are critical for improving our knowledge of glaciovolcanic hazards and our ability to use glaciovolcanic deposits for paleoclimate reconstructions. However, such measurements are rare because the eruptions tend to be dangerous and not easily accessible. To address these difficulties, we conducted a series of pilot experiments designed to allow close observation, measurements, and textural documentation of interactions between basaltic melt and ice. Here we report the results of the first experiments, which comprised controlled pours of as much as $300 \mathrm{~kg}$ of basaltic melt on top of ice. Our experiments provide new insights on (1) estimates for rates of heat transfer through boundary layers and for ice melting; (2) controls on rates of lava advance over ice/ snow; (3) formation of lava bubbles (i.e., Limu o Pele) by steam from vaporization of underlying ice or water; and (4) the role of within-ice discontinuities to facilitate lava migration beneath and within ice. The results of our experiments confirm field observations about the rates at which lava can melt snow/ice, the efficacy with which a boundary layer can slow melting rates, and morphologies and textures indicative of direct lava-ice interaction. They also demonstrate that ingestion of external water by lava can create surface bubbles (i.e., Limu) and large gas cavities. We propose that boundary layer steam can slow heat transfer from lava to ice, and present evidence for rapid isotopic exchange between water vapor and melt. We also suggest new criteria for identifying ice-contact features in terrestrial and martian lava flows.

\section{INTRODUCTION}

Gaining a more quantitative understanding of how lava flows interact with snow and ice is critical for improving our understanding of hazards at snow/ice-covered volcanoes, and for improving our ability to recognize ancient deposits formed by lava and ice interaction. More than 200 terrestrial volcanoes that are currently covered by ice or seasonal snow (Siebert and Simkin, 2002; World Glacier Monitoring Service and National Snow and Ice Data Center, 2012) pose heightened risks from potential rapid melting during lava effusion. In the past $30 \mathrm{yr}$, volcanoes ranging from Mount Veniaminoff, Alaska (1983 eruption; Fig. 1A), to Cerro Hudson, in southern Chile (1991 eruption), to the Mediterranean (Mount Etna, ongoing) have produced supra-ice/snow lava flows (Siebert and Simkin, 2002), several of which caused local snow/ice melting and flooding (Major and Newhall, 1989). Belousov et al. (2011) demonstrated that interactions between lava and ice/ snow can produce dangerous explosions. Eruptions at ice-covered volcanoes have the potential to indirectly destroy local resources of freshwater via melting of climate-stressed glaciers (e.g., Gigjökull glacier, Iceland, in 2010). However, while many instances of lava-ice/snow interactions have been reported from historic eruptions (e.g., the 1947 Hekla eruption in Iceland; Einarsson, 1949), few if any quantitative measurements have been made of heat transfer during syneruption lava-ice interactions.

Similarly, while many workers have interpreted physical features found in ancient effusive deposits as having resulted from interaction between lava and ice/snow, relatively few studies examining historic deposits have been reported (e.g., Edwards et al., 2012), and much of the evidence, such as the presence of pillow lavas, can be ambiguous. Finding definitive criteria for identifying lava flows that have directly interacted with ice/snow is increasingly important as glaciovolcanic deposits continue to become standard paleoclimate proxies for constraining ice presence and thickness on Earth (e.g., Smellie et al., 2008) and on Mars (Chapman et al., 2000).

Field measurements and close observations of interactions between lava and ice/snow are rare because (1) eruption sites are frequently inaccessible, (2) unpredictable eruption behavior can make field studies hazardous, and/or (3) the eruptions frequently occur in locations where weather conditions and terrain impede on-site measurements. To address these difficulties, we conducted a series of experiments involving the pouring of large volumes $(\sim 100 \mathrm{~kg})$ of melted basalt over layers of ice as much as $12 \mathrm{~cm}$ thick (Figs. 1B and 1C). The experimental setup, housed at Syracuse University (New York, USA) and jointly run by the College of
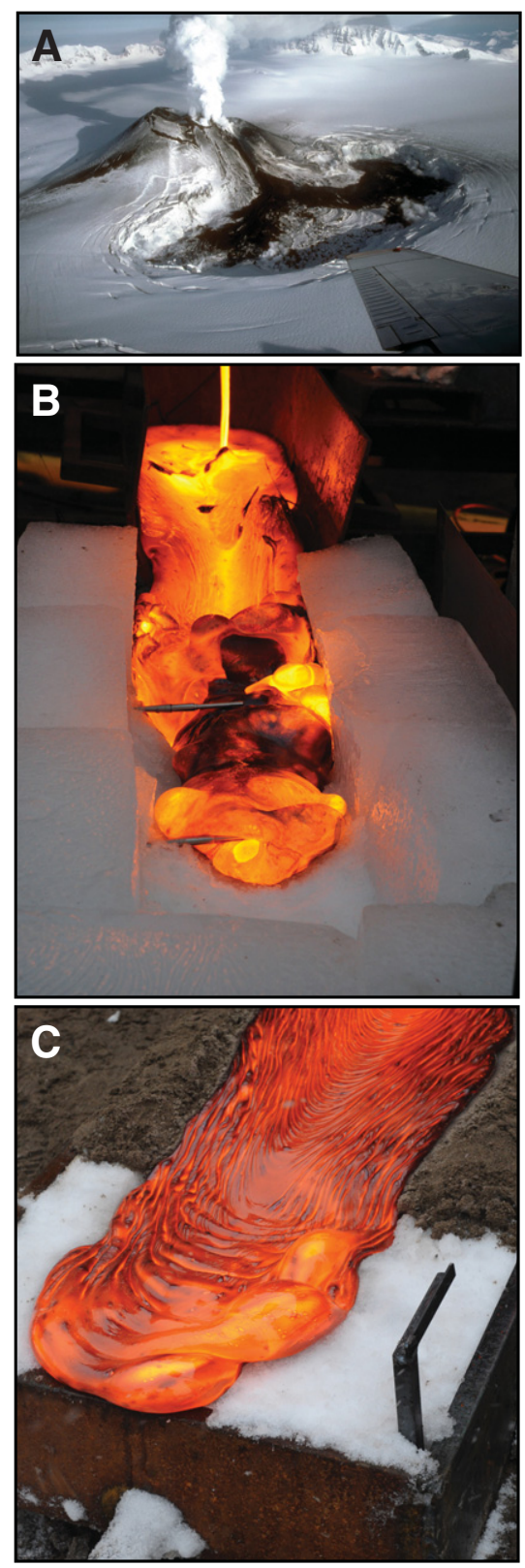

Figure 1. Natural and experimental lava flows advancing on ice and snow. A: Lava flow emplaced into ice-filled caldera during 1983 eruption at Mount Veniaminof, Alaska (photo by E. Yount, Alaska Volcano Observatory, U.S. Geological Survey). Pit in ice is $\sim 1300 \mathrm{~m}$ wide. B: Lava flowing over bed of ice $12 \mathrm{~cm}$ thick. Lava flow is $15 \mathrm{~cm}$ wide. $\mathrm{C}$ : Lava flowing over snow $12 \mathrm{~cm}$ thick. Lava flow is $\sim 20 \mathrm{~cm}$ wide. 
Visual and Performing Arts Sculpture Program and the Department of Earth Sciences (Karson and Wysocki, 2012; http://lavaproject.syr. edu), facilitated quantitative measurements of the behavior of the melt advancing across and through ice/snow. During the experiments we were able to observe closely and monitor the nature of melt-ice/snow interaction (see Video DR1 in the GSA Data Repository ${ }^{1}$ ). We measured rates of snow/ice melting, rates of melt cooling, and rates of heat transfer through boundary layers at the interface of the melt and ice/snow. We also documented flow morphologies resulting from ice confinement, controls on rates of melt advance, and the production of gas bubbles via steam entrapment beneath the lava. To our knowledge, these are the largest scale experiments designed to investigate lava-ice/ snow interactions, and they provide new tests of hypotheses formulated from field observations of historic (e.g., 1947 Hekla) and recent (e.g., 2010 Fimmvörðuháls, Iceland) eruptions.

\section{METHODS}

Seven experiments were conducted during January-March of 2011 and 2012 at Syracuse University. The experiments all used the same basaltic starting material (Keweenaw Chengwatana Volcanic Group basalt; Wirth et al., 1998), which was melted in a commercial gas-fired furnace at superliquidus temperatures $\left(>1300{ }^{\circ} \mathrm{C}\right)$. During the experiments, 75 to $\sim 300 \mathrm{~kg}$ of melt were extruded onto three different types of sloping surfaces $\left(5^{\circ}-10^{\circ}\right)$ : (1) continuous sheets of ice, (2) platforms made of ice blocks, and (3) shaved ice (simulating lowerdensity snow). In several experiments, the ice surfaces were covered by a layer of $1-3 \mathrm{~cm}$ of quartz sand to simulate ash-covered snow. The paths of the melts were confined either by ice blocks or mounded ice shavings. The containers ( $1 \mathrm{~m}$ long by $0.5 \mathrm{~m}$ wide) allowed continuous water drainage through a basal pipe, at which meltwater temperatures and discharge rates were measured. During five experiments in 2012, the temperatures of drainage water, of lava flow bases, and of the sand-ice/snow interface were measured at $2 \mathrm{~s}$ intervals with K-type thermocouples and digital data loggers. Measurements of $\mathrm{H}$ and $\mathrm{O}$ isotopes on samples of volcanic glass from the experiments were performed at the University of Oregon using methods described by Bindeman et al. (2012). For some experiments, flow velocities were measured quantitatively by continuous video recordings using the optical flow method described in Lev et al. (2012).

${ }^{1}$ GSA Data Repository item 2013237, supplemental video, is available online at www.geosociety.org/pubs /ft2013.htm, or on request from editing@ geosociety.org or Documents Secretary, GSA, P.O. Box 9140, Boulder, CO 80301, USA.

\section{RESULTS}

Melt-ice interactions observed during the course of the seven experiments shared many similarities (see http://lavaproject.syr.edu for links to online videos of selected experiments). All flows had smooth, pahoehoe-like surfaces (Figs. 1B and 1C). Melt flow rates across all substrates were typically between $5 \mathrm{~cm} \mathrm{~s}^{-1}$ and $10 \mathrm{~cm} \mathrm{~s}^{-1}$, and much of the melting occurred after the maximum flow length $(\sim 0.8 \mathrm{~m})$ had been established. At boundaries where the melt had directly contacted ice/snow, bulbous, vitric surface textures formed; all flows cooled to an essentially crystal-free glass. Melting of ice was most rapid immediately after the emplacement of the flows, and was faster beneath the flows than along the flow sides or in sub-ice tunnels.

However, significant differences were observed between experiments with and without sand layers. Flows in direct contact with ice generally bubbled vigorously, with bubble production much more pronounced for flows on massive ice than for those on shaved ice. Conversely, experiments where a layer of sand separated the melt from the underlying ice produced fewer bubbles. For experiments without sand layers, the flows were initially able to move across the ice substrate, but eventually sinking of the lava into the ice started to inhibit further advance; experiments with sand layers produced slow and more uniform sinking of flows through the ice. However, once the melt reached the bottom of the container, it continued to advance laterally and downslope along discontinuities in the ice and along the ice-container boundary.

Differences were also prominent for experiments where the ice surface had physical discontinuities. Flows poured onto tightly packed ice blocks rapidly exploited the small spaces between blocks to move through, and eventually along, the bottom of the ice; this allowed melting of ice in a three-dimensional network and encouraged sinking of the lava flow through the ice. The resulting flows showed unique morphologies with distinct flow margin levees formed as the melt sank through the ice, and also contained cavities showing the former positions of ice blocks.

\section{DISCUSSION}

\section{Heat Transfer and Melting Rates}

The experiments reproduced two endmember behaviors that have been observed or inferred from historic eruptions, i.e., flows that melted very rapidly through ice (e.g., the 1984 Villarica eruption in Chile; Major and Newhall, 1989) and flows that moved over snow with little initial melting (e.g., 2010 Fimmvörðuháls eruption; Edwards et al., 2012). The estimated rates at which lava sank via melting of underlying ice or snow during the experiments confirm observations of lava flows rapidly disappearing beneath ice during historic eruptions of volcanoes like Villarica (Major and Newhall, 1989). Observed sinking rates were as fast as $5 \times 10^{-4} \mathrm{~m} \mathrm{~s}^{-1}$ for flows $10 \mathrm{~cm}$ thick, and were sustained through at least $12 \mathrm{~cm}$ of ice. The observed minimum vertical melting rate, $\sim 5$ $\times 10^{-4} \mathrm{~m} \mathrm{~s}^{-1}(\Delta x / \Delta t)$, implies a basal heat flux (q) of $\sim 1.5 \times 10^{5} \mathrm{~W} \mathrm{~m}^{-2}$, using standard thermodynamic properties for ice (Edwards et al., 2012). The implied flux is within the range of heat flux estimates by Gudmundsson (2003) for conductive cooling of pillow lavas in subglacial environments. Measurements of meltwater temperatures taken during the course of the experiments show that the meltwater was heated to temperatures $>50{ }^{\circ} \mathrm{C}$ for several minutes, and some meltwater was converted to steam (Fig. 2). Given that the best estimates of initial melt temperatures, constrained by infrared cameras and thermocouples, are generally close to $1200{ }^{\circ} \mathrm{C}$, and that the crystallinity of the resulting glass is close to zero, the total sensible heat available from the basaltic flow for melting, heating, and vaporization during the period of fastest melting is $5.7 \times 10^{5} \mathrm{~J} \mathrm{~kg}^{-1}$. Melting through the entire thickness of ice and heating the resulting pure water to the temperatures measured at the base of the ice requires $5.4 \times 10^{5} \mathrm{~J} \mathrm{~kg}^{-1}$; production of steam requires significantly more energy $(\sim 28.3$ $\left.\times 10^{5} \mathrm{~J} \mathrm{~kg}^{-1}\right)$. Our estimated heat flux is similar

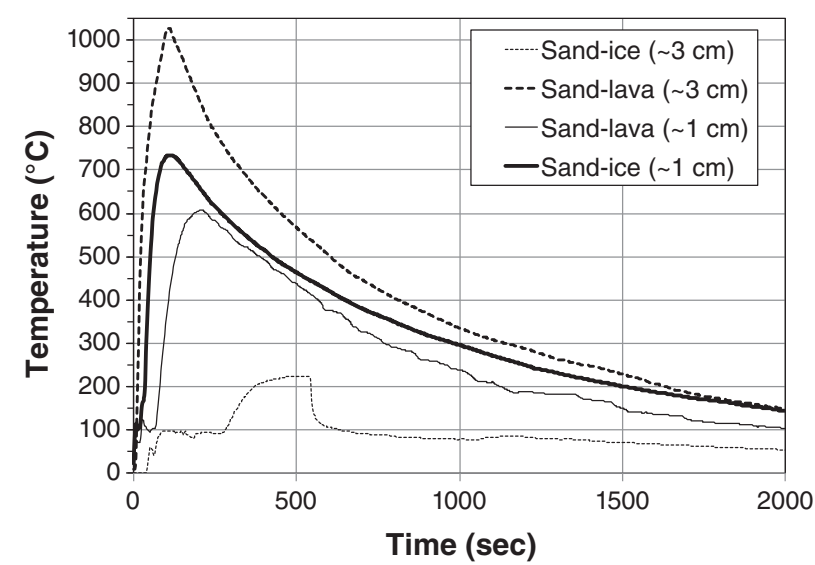

Figure 2. Temperatures above and below sand boundary layers separating lava and ice for two different boundary layer thicknesses $(1 \mathrm{~cm}$ and $3 \mathrm{~cm})$. 
to rates predicted by Wilson and Head (2007) for conduction of heat from the base of lava flows. Measurements of temperatures above and below layers of sand between lava and underlying ice agree in general with predictions that thicker boundary layers will slow melting (Fig. 2); peak temperatures at the base of the $\sim 1 \mathrm{~cm}$ sand layer are higher and rise more quickly than for the $\sim 3 \mathrm{~cm}$ sand layer. Thermocouples also appear to record the periods when the temperature at the boundary between the underlying ice and the overlying sand is held constant at $100{ }^{\circ} \mathrm{C}$ by the conversion of water to steam (Fig. 2); this phase transition lasts for $\sim 5 \mathrm{~min}$, after which time the ice/water is no longer present, so the thermocouple temperature continues to rise while heat is transferred through the sand from the overlying lava flow.

Major and Newhall (1989) documented 15 examples of lava flows traveling over ice or snow, and described at least three other eruptions that might have produced lava-ice/snow contact. They found that although of a few of those examples had produced significant lahars, most had not produced significant amounts of meltwater. Our experiments shed further light on these observations in two ways. First, visually estimated rates of meltwater discharge indicate that it is faster for experiments using ice blocks than for shaved ice. Second, melting rates were slower during experiments with sand layers separating the lava and ice. It is possible that for some of the examples described by Major and Newhall (1989), lava flows traveled over tephracovered ice/snow where the insulating effects slowed melting significantly, so that even if a large volume of ice/snow had been melted, it was released slowly enough that lahars or floods were not generated. In addition, lava that flowed over snow or permeable ice would appear to generate less meltwater, as the water discharge would be more diffuse. However, our experiments also demonstrate the power of lava flows to melt rapidly bare ice; thus, the experiments demonstrate the importance of knowing the spatial distribution and thickness of tephra or debris on ice before the onset of lava effusion to better assess possible flood or lahar hazards at snow/ ice-covered volcanoes.

\section{Supra-Ice Flows}

One of the most intriguing observations from the experiments is the ability of lava to hydroplane across an inclined ice surface. When poured directly on top of ice tilted at $5^{\circ}-10^{\circ}$, a meltwater lens rapidly forms beneath and ahead of the lava flow, which appears to skate across the top of the ice at a rate estimated to be tens of centimeters per second; preliminary experiments with a dry ice substrate showed similar results, and are consistent with trapping of a vapor phase at the ice-lava flow boundary (the Leidenfrost effect) and increasing flow velocity.
However, in experiments where melt advanced on shaved ice or ice covered with a layer of sand, the higher porosity and insulation prevented the formation of an obvious water or steam layer even though the flows were still moving $5-10 \mathrm{~cm} \mathrm{~s}^{-1}$; water infiltration into the shaved ice may lessen the steam production needed for the skating. High flow rates due to trapped basal water or steam may have produced the explosive interactions documented by Belousov et al. (2011). Lava flow rates $>\sim 5-10 \mathrm{~m} \mathrm{~h}^{-1}(\sim 1 \mathrm{~cm}$ $\left.\mathrm{s}^{-1}\right)$ are faster than melting rates due to maximum heat transfer via radiant heating, and will facilitate supraglacial lava flows (Wilson and Head, 2007; Edwards et al., 2012). This type of lava flow seems likely to cause the most significant melting of underlying snow/ice because the lava remains in direct contact with the ice.

\section{Formation of Limu o Pele}

One of the most impressive sights during the experiments without sand layers is the rapid and extensive formation of large bubbles (Limu o Pele). Maicher and White (2001) reviewed observations on Limu production in Hawaii and speculated that even deep-sea eruptions could produce Limu if a lava flow engulfed water and the water was rapidly heated to the point of producing steam. However, the present experiments are, to our knowledge, the first published large-scale demonstration of Limu produced by water derived from melting of underlying ice. We measured the $\mathrm{O}$ and $\mathrm{H}$ isotopes within samples of bubble-wall glass to investigate possible interactions between vapor and melt.
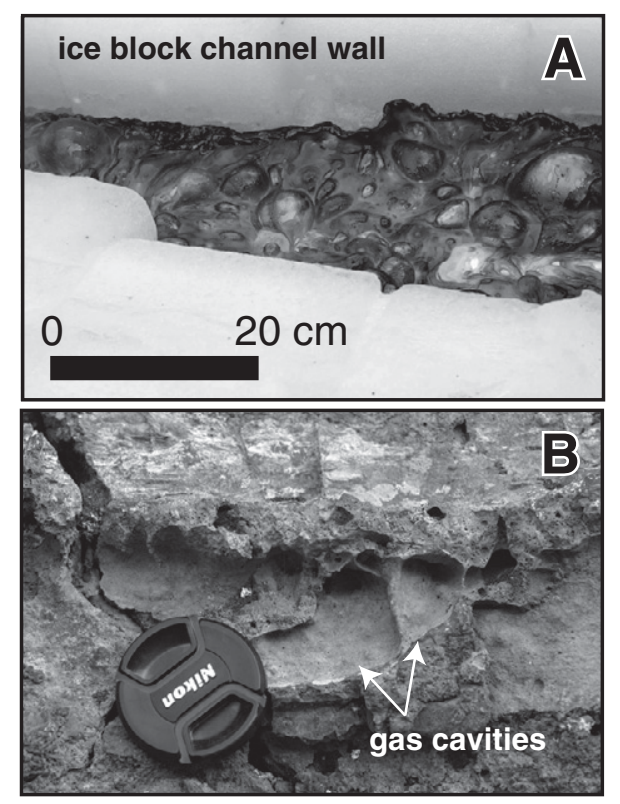

Figure 3. Examples of experimental formation of Limu o Pele. A: Bubbly surface in advancing experimental lava flow. Lava is $\sim 20 \mathrm{~cm}$ wide. B: Large gas cavities in glaciovolcanic lava flow, British Columbia, western Canada.
Although no meteoric water gain was detected (and thus no measurable $\mathrm{H}$ isotope effects), we documented a measurable $0.30 \%$ o shift in glass $\delta^{18} \mathrm{O}$ values (from $11.70 \%$ in starting melt to $11.40 \%$ in bubble wall) exclusively in thin glass surrounding bubble walls. Although the melting process for the starting material ensures that the starting melt is degassed, even during an experiment where the ice layer was relatively thin $(\sim 5 \mathrm{~cm})$, large (typically $2-10 \mathrm{~cm}$ in diameter) bubbles formed where the flow moved on top of the ice and began to melt through it. The abundance of bubbles is a compelling argument for the role of external water in producing Limu (Fig. 3A). Temperature measurements from thermocouples at the base of the lava flow indicate that the flows remained above their glass transition temperature $\left(\sim 700{ }^{\circ} \mathrm{C}\right)$ for several minutes, facilitating upward movement of vapor into hotter flow interiors (Fig. 3A). Non-ice experiments where melt flowed over wet sand also led to the formation of bubbles, although they were much less abundant than those produced in the lava-ice experiments; lava flows over dry sand do not produce bubbles. Although not well described in the literature, glaciovolcanic lava flows observed by us in Iceland and British Columbia (Canada) also have areas that are anomalously vesicular, even when located distally from the vent area (e.g., Fig. 3B); research on the formation of rootless cones is consistent with the ability of lava flows to trap steam beneath the flows, allowing for eventual explosive release of steam (Hamilton et al., 2010). Recognition of vesicles produced by external water sources has important implications for using volatiles in volcanic glass as a paleo-ice/water indicator (Tuffen et al., 2010), because the presence of vesicles is a necessary criterion for determining that the glass was in equilibrium with a vapor phase. However, if the vesicles formed from external water, they may invalidate that criterion and compromise estimates of paleo-ice thicknesses. Anomalously high vesicularity in lava flows may be another criterion for identifying lava flows that have traveled over snow/ice. In addition, our $\mathrm{O}$ and $\mathrm{H}$ isotopic measurements provide a first step in determining whether isotopic shifts can be used to detect lava-ice interactions.

\section{Flow Morphologies and Ice Discontinuities}

Experiments also highlight the ability of lava to exploit discontinuities (e.g., crevasses) to burrow downward and move beneath and through volumes of ice. The resulting trellis patterns of small, pillow-like lava lobes have been observed in several experiments (Fig. 4A) and are similar to lava patterns seen at the lower end of the Gigjökull trachyandesite lava flow formed during the 2010 Eyjafjallajökull eruption (Fig. 4B). Cuspate geometries at the boundaries between lava and snow/ice during 

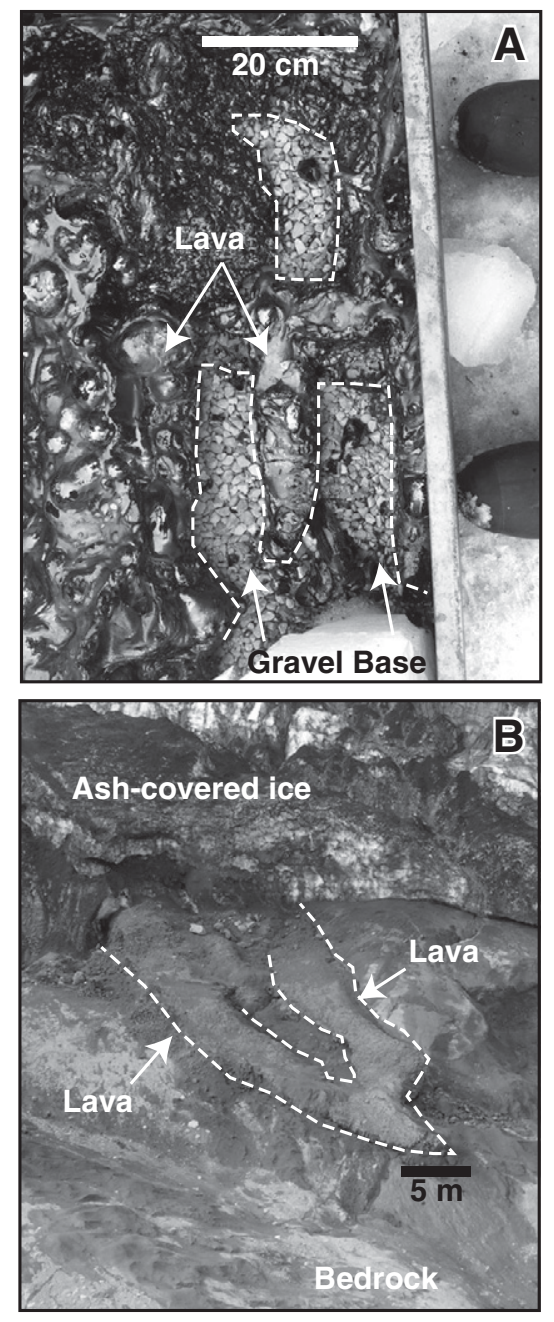

Figure 4. Experimentally produced ice-molded lava morphology and possible natural equivalent. A: View looking down on top of latticeshaped experimental lava flow mimicking boundaries of ice blocks, which have been removed to expose gravel substrate beneath. Isolated lava lobe is $5 \mathrm{~cm}$ wide. B: Latticeshaped lava flow from Gigjökull, Iceland. Junction of two lava flows is $\sim 5 \mathrm{~m}$ wide.

the experiments are similar to features seen in Iceland (Edwards et al., 2012). The ability to control ice-lava boundary starting geometries during experiments provides a powerful new method for testing field-based hypotheses about ice confinement of lava flows, further enhancing the usefulness of ancient glaciovolcanic lava flows as paleoclimate proxies by documenting locations of ice discontinuities and sub-ice drainage networks in areas formerly covered by ice on Earth and Mars.

\section{CONCLUSIONS}

The experiments described herein have produced the first close observations and quantitative measurements of how basaltic melt interacts with ice. The experiments confirm recently proposed ideas, based on the 2010 eruptions in Iceland, about the ability of lava to advance on top of snow (Edwards et al., 2012). They also demonstrate that gas cavities in lava flows can be the result of introduction of external water, which is a cautionary constraint for interpretations of large gas cavities in lava flows erupted into an environment with abundant external water. The textures and morphologies observed during the experiments may also provide new criteria for recognition of lava-ice interactions on Earth and Mars, increasing the potential for recognition of those deposits and facilitating their use as paleoclimate proxies.

\section{ACKNOWLEDGMENTS}

Edwards acknowledges funding from National Science Foundation (NSF) grant EAR-0910712 and Dickinson College (Pennsylvania); Karson and Wysocki acknowledge funding by the central Administration of Syracuse University (New York). Lev was funded by a Lamont-Doherty Earth Observatory Postdoctoral Fellowship and NSF grant EAR-1118943. We thank Noah Hausknecht and Phillip Evans for expert handling of experimental melts and rapid equipment manufacturing, and several other observers for helping with photography and meltwater collection (Tracy Gregg and students from the State University of New York at Buffalo, Matt Kissane, Alex Lloyd, and Jenni Wysocki). We thank M.T. Guðmundsson and B. Oddsson for useful discussions (with Edwards) and for providing logistical support for examination of the Gigjokull lava flow in 2010-2012. Comments by D. Geist, R. Herd, and an anonymous reviewer helped us to clarify and strengthen the text.

\section{REFERENCES CITED}

Belousov, A., Behncke, B., and Belousova, M., 2011, Generation of pyroclastic flows by explosive interaction of lava flows with ice/water-saturated substrate: Journal of Volcanology and Geothermal Research, v. 202, p. 60-72, doi:10.1016/j .jvolgeores.2011.01.004.

Bindeman, I.N., Kamenetsky, V.S., Palandri, J., and Vennemann, T., 2012, Hydrogen and oxygen isotope behaviours during variable degrees of upper mantle melting: Example from the basaltic glasses from Macquarie Island: Chemical Geology, v. 310-311, p. 126-136, doi:10.1016/j .chemgeo.2012.03.031.

Chapman, M.G., Allen, C.C., Gudmundsson, M.T., Gulick, V.C., Jakobsson, S.P., Lucchitta, B.K., Skilling, I.P., and Waitt, R.B., 2000, Volcanism and ice interactions on Earth and Mars, in Gregg, T.K.P. and Zimbelman, J.R., eds., Deep oceans to deep space: Environmental effects on volcanic eruptions: New York, Plenum Press, p. 39-74.

Edwards, B.R., Magnusson, E., Thordarson, T., Gudmundsson, M.T., Hoskuldsson, A., Oddsson, B., and Haklar, J., 2012, Interactions between lava and snow/ice during the 2010 Fimmvörðuhals eruption, south-central Iceland: Journal of Geophysical Research, v. 117, B04302, doi:10.1029 /2011JB008985.

Einarsson, T., 1949, The flowing lava: Studies of its main physical and chemical characteristics, in Einarsson, T., et al., eds., The eruption of Hekla 1947-1948: Reykjavik, Iceland, Societas Scientiarum Islandica, Visindafdag Islendiga, p. 1-70.
Gudmundsson, M.T., 2003, Melting of ice by magmaice-water interactions during subglacial eruptions as an indicator of heat transfer in subaqueous eruptions, in White, J., et al., eds., Explosive subaqueous volcanism: American Geophysical Union Geophysical Monograph 140, p. 61-72, doi:10.1029/140GM04.

Hamilton, C., Fagents, S., and Thordarson, T., 2010, Explosive lava-water interactions II: Self-organization processes among volcanic rootless eruption sites in the 1783-1784 Laki lava flow, Iceland: Bulletin of Volcanology, v. 72, p. 469485, doi:10.1007/s00445-009-0331-5.

Karson, J., and Wysocki, R., 2012, Do-it-yourself lava flows: Science, art and education in the Syracuse University Lava Project: Earth Magazine, August-October, http://www.earthmagazine.org /article/do-it-yourself-lava-flows.

Lev, E., Spiegelman, M., Karson, J., and Wysocki, R., 2012, Investigating lava flow rheology using video analysis and numerical flow models: Journal of Volcanology and Geothermal Research, v. $247-248$, p. $62-73$, doi:10.1016/j.jvolgeores .2012.08.002

Maicher, D., and White, J.D.L., 2001, The formation of deep-sea Limu o Pele: Bulletin of Volcanology, v. 63, p. 482-496, doi:10.1007/s004450100165.

Major, J.J., and Newhall, C.G., 1989, Snow and ice perturbation during historical volcanic eruptions and the formation of lahars and floods: Bulletin of Volcanology, v. 52, p. 1-27, doi:10.1007 /BF00641384.

Siebert, L., and Simkin, T., 2002, Volcanoes of the world: An illustrated catalog of Holocene volcanoes and their eruptions: Smithsonian Institution Global Volcanism Program Digital Information Series GVP-3, http://www.volcano.si.edu/world /eruptioncriteria.cfm (accessed 16 March 2012).

Smellie, J.L., Johnson, J.S., and McIntosh, W.C., 2008 , Six million years of glacial history recorded in volcanic lithofacies of the James Ross Island Volcanic Group, Antarctic Peninsula: Palaeogeography, Palaeoclimatology, Palaeoecology, v. 260 , p. 122-148, doi:10.1016/j.palaeo .2007 .08 .011

Tuffen, H., Owen, J., and Denton, J.S., 2010, Magma degassing during subglacial eruptions and its use to reconstruct paleo-ice thicknesses: EarthScience Reviews, v. 99, p. 1-18, doi:10.1016/j .earscirev.2010.01.001.

World Glacier Monitoring Service and National Snow and Ice Data Center, compilers, 1989, World glacier inventory: Zurich, Switzerland, World Glacier Monitoring Service, and Boulder, Colorado, National Snow and Ice Data Center, digital media, http://nsidc.org/data/docs/noaa/g01130_ glacier_inventory (updated 2012).

Wilson, L., and Head, J.W., 2007, Heat transfer in volcano-ice interactions on Earth: Annals of Glaciology, v. 45, p. 83-86, doi:10.3189 $/ 172756407782282507$.

Wirth, K.R., Cordua, W.S., Kean, W.F., Middleton, M., and Naiman, Z.J., 1998, The geology of the southeastern portion of the Midcontinent Rift System, eastern Minnnesota and western Wisconsin: Saint Paul, Minnesota, Institute on Lake Superior Geology Field Trip Guidebook, v. 44, p. 33-75.

Manuscript received 12 December 2012

Revised manuscript received 14 March 2013

Manuscript accepted 14 March 2013

Printed in USA 